Ilmenau University of Technology

Institute of Economics

Ilmenau Economics Discussion Papers, Vol. 19, No. 89

The Behavioural Economics of Competitive Balance: Implications for League Policy and Championship Management

Oliver Budzinski \& Tim Pawlowski

September 2014

Institute of Economics

Ehrenbergstraße 29

Ernst-Abbe-Zentrum

D-98 684 Ilmenau

Phone 03677/69-4030/-4032

Fax 03677/69-4203

http://www.wirtschaft.tu-ilmenau.de

ISSN 0949-3859 


\title{
The Behavioural Economics of Competitive Balance: Implications for League Policy and Championship Management
}

\author{
Oliver Budzinski* \& Tim Pawlowski ${ }^{\#}$
}

\begin{abstract}
The theory of competitive balance represents one of the core concepts of sports economics. Based upon an international research project analyzing the perception of competitive balance by consumers (Pawlowski 2013a, 2013b; Pawlowski \& Budzinski 2013, 2014), we argue in this paper that behavioural explanations of competitive balance may offer additional insights for selected sports economics and, in particular, sports policy problems, complementing the standard view on competitive balance. After summarizing the standard analysis of competitive balance in sports economics concerning theory, policy and empirical record in chapter 2 , we report the main theoretical and empirical insights from our research project (chapter 3, closely drawing on the respective publications). In addition to providing a more comprehensive picture of the behavioural economics of competitive balance, we add a discussion of sports policy implications (chapter 4). While perceived competitive balance is found to matter, there are rather narrow conditions for sports policy interventions or restrictive regulations of competition by the league management (or sports associations). Furthermore, it is not the balance of the overall league that matters. Instead, it is sufficient or even advantageous if the most relevant subcompetitions, like the race for the championship or the fight against relegation, are 'balanced' among a narrow oligopoly of contenders.
\end{abstract}

Keywords: sports economics, sports policy, sports management, competitive balance, behavioural economics, competitive balance defense

JEL classification: D12, L83

\footnotetext{
* Professor of Economic Theory, Institute of Economics, Ilmenau University of Technology, Ehrenbergstraße 29, D-98698 Ilmenau, Email: oliver.budzinski@tu-ilmenau.de.

\# Professor of Sports Economics, Sports Management \& Sports Media Research, Institute of Sports Sciences, University of Tübingen, Wilhelmstraße 124, D-72074 Tübingen, Email: tim.pawlowski@uni-tuebingen.de. The author gratefully acknowledges the financial support provided by an UEFA Research Grant.
} 


\section{Introduction}

Ever since the seminal pioneering work of Rottenberg (1956), competitive balance has been viewed as a major element of sports economics and largely responsible for economic success of professional sports business. The standard notion of competitive balance typically relates to the overall balance of a sports league or championship, i.e. the competitive closeness of all participants in the contest. Consequently, the empirical branch of sports economics has predominantly employed league-global or championship-global measures in order to estimate competitive balance in its effects. In line with the research focus of sports economics, competitive balance issues and reasoning have been a major driving-force of sports policy interventions and regulations.

Based upon an international research project analyzing the perception of competitive balance by consumers (Pawlowski 2013a, 2013b; Pawlowski \& Budzinski 2013, 2014), we argue in this paper that behavioural explanations of competitive balance may offer additional insights and a more appropriate approach for selected sports economics and, in particular, sports policy problems. While we find that perceived competitive balance does matter, we also conclude rather narrow conditions for sports policy interventions or restrictive regulations of competition by the league management (or sports associations). Moreover, it is not the balance of the overall league that influences fans' behaviour. Instead, it is sufficient - or even advantageous in the eyes of the fans - if the most relevant subcompetitions, like the race for the championship or the fight against relegation, are 'balanced' among a narrow oligopoly of contenders. After summarizing the standard analysis of competitive balance in sports economics in the dimensions theory, policy and empirical record in chapter 2, we report the main theoretical and empirical insights from our research project (chapter 3, closely drawing on the respective publications). Next to providing a more comprehensive picture of the behavioural economics of competitive balance, we add a discussion of sports policy implications (chapter 4).

\section{The Uncertainty-of-Outcome Hypothesis and Competitive Balance}

\subsection{Standard Theory of Competitive Balance}

The concepts of the uncertainty-of-outcome hypothesis (UOH) and competitive balance have been highlighted as distinctive features of the economics of sports from the beginnings of sports economics research, pioneered by Rottenberg (1956) and Neale (1964), on. The UOH describes an important motive why consumers find attending or watching sports events exciting and entertaining. Next to the absolute quality of the product - the level of talent, extraordinary skills or athletic prowess it is the relative quality of the competition among sports teams or athletes that creates entertainment value for the spectators. This relative quality manifests itself 
in the unpredictability of the competition results: the uncertainty of outcome. If spectators knew in advance how a sporting competition would play out and end, the utility gained from consuming this product would be rather low. For instance, re-runs of past seasons of premier league football ${ }^{1}$ (or other team sports) attract a tiny fraction of the viewers of live broadcasts or other first-time broadcasts (summary programs, time-delayed broadcasts) of new games. The hypothesis in sports economics, thus, has always been that the uncertainty of outcome critically influences the (marginal) utility for consumers and, consequently, drives the willingnessto-pay for attending or watching sports events. Accordingly, an increasing uncertainty of outcome increases (marginal) utility and, therefore, at any given price, increases demand (D) (for tickets/stadium attendance or broadcasts) - and revenues (R) for the suppliers of the sports product (clubs, leagues, athletes, etc.). This is the fundamental content of the $\mathrm{UOH}$.

Because the $\mathrm{UOH}$ plays such a central role for the business of sports, the question arises what are the driving-forces of outcome uncertainty. Again, rooted in the pioneering works of sports economics (Rottenberg 1956; Neale 1964), the standard reasoning emphasizes the role of the closeness of competitiveness among the competitors. The degree of outcome uncertainty depends on degree of disparity between the competitors: the bigger the performance gap between 'strong' and 'weak' teams, the higher is competitive imbalance. Or, the other way around, if the competitors in a league or championship are of equal strength, then competitive balance is at its maximum. Theoretically, perfect competitive balance in a football league implies that each team enjoys the same probability to win in respect to each game. Thus, the notion of competitive balance $(\mathrm{CB})$ refers to the balance of competitiveness among the participants of a sports contest. Combining the concepts of $\mathrm{UOH}$ and $\mathrm{CB}$ yields that high competitive balance is in the economic interest of all participants of a sporting contest since: $\mathrm{CB} \uparrow \rightarrow \mathrm{UO} \uparrow \rightarrow \mathrm{D} \uparrow \rightarrow \mathrm{R} \uparrow$.

This insight is of palmary importance for sports economics and sports policy because it defines a distinctive difference between sports markets and ordinary markets: whereas in ordinary markets each competitor has an unambiguous interest to become the market leader also at the expense of other competitors (and even by deterring the competitive fringe by establishing a monopoly), competitors in sports markets are in need of each other in order to provide an economically viable product. Moreover, they do not only need to allow their competitors to survive, they also have an individual as well as a common incentive to preserve the competitiveness of their competitors. ${ }^{2}$ In the words of Rottenberg (1956: 242, 246): „The na-

\footnotetext{
${ }^{1}$ If not specifically emphasized otherwise, the term "football" refers to European-style football (sometimes also called soccer) throughout this paper.

${ }^{2}$ It should be emphasized that it is in the economic interest of each participant to preserve the competitiveness of the others - but not in the sportive interest (the desire to win).
} 
ture of the industry is such that competitors must be of approximately equal "size" if any are to be successful; this seems to be a unique at-tribute of professional competitive sports. (...) That is to say, the "tighter" the competition, the larger the attendance". "'Oh Lord, make us good, but not that good,' must be the prayer" (Neale 1964: 2).

Along the lines of this pioneering reasoning, economic models have been developed starting with the seminal work of El-Hodiri \& Quirk (1971). Fundamentally, they model professional sports leagues with two profit maximizing teams and fixed talent supply (for extensions and modifications see Fort \& Quirk 1995 and Vrooman 1995). They compare the noncooperative equilibrium (the competition case) with the cooperative equilibrium (the cartel or monopoly case). If the marginal revenue functions of the two teams differ with one representing a big-market team and the other one a small-market team, then competitive balance in the cooperative equilibrium is (under some additional conditions and assumptions) higher than in the noncooperative equilibrium. Since more competitive balance, however, is welfaremaximizing, regulatory interventions to increase competitive balance may be justified in the case of differing financial strengths of the teams. Thus, theory adds the important insight that differences in the financial potential of the teams lead to competitive imbalance, providing the theoretical fundament for equalizing policy interventions (financial level-playing field).

However, some authors have extended this modeling framework in a way that casts doubt on some of the central results (Szymanski \& Késenne 2004; Szymanski 2006a). By emphasizing the magnitude of marginal revenue changes due to additional wins, they conclude that a noncooperative Nash-equilibrium of the modified sports league model includes more competitive balance than the cooperative equilibrium and the social optimum because allocating additional wins to the team with the higher marginal revenue (the big-market team) increases total profits. Thus, (some) imbalance is profit-maximizing.

The reasoning that consumers may actually prefer (some) imbalance is further reinforced by considerations of absolute quality. The economic theory of superstars and stardom emphasizes the preference of consumers to witness the best: secondbest talent can be a poor substitute for first-best talent (Rosen 1981), known talent qualities may be preferred to unknown new talent (MacDonald 1988), and positive network externalities including boulevard externalities may increase the consumption utility if superstar teams or athletes are present (Adler 1985; Franck \& Nüesch 2007). Superstars - by their very definition - create imbalance, still superstar phenomena involve economic value. Thus, witnessing a superstar (team or athlete) dominating a sport may be exciting for consumers ${ }^{3}$, at least under yet-to-be-

\footnotetext{
${ }^{3}$ Without the imbalance-creating successes of stars like Boris Becker, Michael Schumacher or Tiger Woods, their respective sports would hardly have experienced such an upward swing of sports
} 
specified circumstances. So far, the economics of superstars have not yet been systematically integrated into the economic modeling of sports (but see Buraimo \& Simmons 2013). However, it seems unlikely that perfect competitive balance, effectively a random walk without any famous competitors, would serve to create an attractive sports product. ${ }^{4}$ It is certainly not accidental that fandom typically concentrates on a few famous competitors in each league or championship, preferably on those with a particularly (imbalanced) high probability of winning. Further considerations along these lines refer to the particular excitement of upsets, i.e. if the underdog beats the favorite, which also require some minimum imbalance (Coates, Humphreys \& Zhou 2014), or to the particular preference of fans attending a match in the stadium to see their favourite home team winning by a clear margin (e.g. Forrest et al. 2005; Coates \& Humphreys 2010, 2012).

In summary, there are good reasons why some competitive balance contributes to consumer welfare but there are also good reasons why some competitive imbalance contributes to consumer welfare. If there is an optimal competitive balance, it still needs to be determined in an empirically and politically meaningful way. In the words of Zimbalist (2002: 111): "Competitive balance is like wealth. Everyone agrees it is a good thing to have, but no one knows how much one needs."

\subsection{Policy Relevance}

The notion that more competitive balance always improves (consumer) welfare has been vital to several types of widespread sports policy implications. In order to understand the peculiar policy problems in professional sports, a look at the typical organization of professional sports is necessary. In contrast to most 'ordinary' markets, professional sports is characterized by market-internal institutions that are established, implemented and enforced by powerful market-internal organizations (the sports associations). The existence of these sports associations is essential for the business of professional sports because any kind of sports needs rules for the sporting competition that must be defined, implemented and enforced. Cooperation on rules among the participants is elementary for the common product to be produced and, in Europe, most sports associations were historically created as syndicates of the sports participants (e.g. the clubs). ${ }^{5}$ However and somewhat inevita-

consumer interest. However, this does not negate the possibility that continuing dominance beyond some yet-to-be defined point may significantly decrease spectators' value and interest.

${ }^{4}$ The utility that parts of the sports audience gain from betting would also decrease if odds were all the same (perfect CB).

5 Taking European football as an example, the clubs are organized in regional and national football associations (like the Deutscher Fußball Bund, DFB, for instance) which are member associations consisting of the clubs or the regional associations. The continental competitions are organized under the competence of the European football association (UEFA), which is a member association consisting of the national football associations as members. All these associations are private 
bly, these sports associations enjoy a lot of power - not only over the sports side but also over the business side. Typical tasks and competences of sports associations include, inter alia,

- setting the rules of the game,

- limiting and controlling entry,

- marketing the common product (inter alia, bundling and selling broadcasting rights), and

- sharing, distributing and re-allocating revenues.

From this list alone (which does not intend to be a complete one), the mixture of sporting and business tasks that sports associations engage in becomes visible. It is virtually impossible to disentangle 'purely sporting' activities from 'business relevant' activities. For instance, rule-setting includes the definition of the number of players in team sports or the length and width of the playing field as well as regulations like gate-revenue sharing, salary caps or transfer payment regulations. Furthermore, even apparently purely sporting rules like the modified definition of the physical characteristics of the competition ball for the FIFA Football World Championship in South Africa may be motivated by commercial considerations, for instance, increasing the probability and frequency of goals.

Consequently, sports associations as the market-internal regulators must be viewed to be important economic players - even though they usually prefer to see themselves as non-business entities just working 'for the good of society'. From an economic perspective, internal market institutions and organizations are usually assessed according to their market power and the incentives that shape their behaviour. With respect to market power, governing associations of professional sports usually constitute regional monopolies. In most professional sports, there is no competition among market-internal regulatory agencies and there is no competition among leagues or championships within a given jurisdiction, either. For instance, there is only one European football association (UEFA), only one in Germany (DFB), etc., and there is only one UEFA Champions League, one Bundesliga, etc. This monopolistic pyramid structure of professional sports market-internal organizations may indeed be more beneficial than competing championships and associations, however, it does generate a position of dominance. Furthermore, these monopolistic associations experience incentives to maximize the revenues and/or profits from marketing the professional sport under their governance. As such, their market power is not without economic concern.

Within this setting, the competitive balance problem plays an important role for market-internal as well as external regulation. The idea that preserving competitive

companies, in some sports and in some countries organized as 'non-for-profit clubs', in other cases as 'ordinary' companies. 
balance is beneficial and/or even necessary for the economic success represents a primary justification for sports associations to regulate business-relevant parts of the sport. Quite frequently, these interventions to promote competitive balance include the implementation of rules and policies that generate/maximize revenues in a non-competitive way, for instance, by

- artificially (over-)limiting entry, for instance, in the FIA Formula One World Championship,

- discriminatory controlling entry, for instance, the '50plus rule' in German football excluding new commercial investors from club ownership but preserving incumbent commercial investments (Budzinski \& Müller 2013: 278283) or in U.S. professional sports leagues,

- outright price cartels, for instance, centralized marketing of broadcasting rights (Budzinski 2012: 52-53, 58-62),

- governing the budgetary behavior of competitors, for instance, (ticket) revenue-sharing arrangements (like in the NFL or the MLB), salary and payroll caps (like NFL, NBA, NHL), direct or indirect budget caps (including the recent UEFA Financial Fair Play regulations ${ }^{6}$ ), draft systems for new player recruitment (like in the NFL or the MLB), etc.,

- implementing internal labour market rules restricting the contractual freedom of the parties (e.g. transfer periods and regulations or restrictions of consulting activities by independent managers), and

- concluding exclusivity contracts with equipment suppliers.

Many of these market-internal policies and regulations cause questionable competition effects and include adverse effects on customers and other related business players. However, they are usually brought forward by highlighting the preservation or improvement of competitive balance as one of the major reasons - a reason that qualifies to overcompensate the adverse effects.

The market-internal policies and regulations by the sports associations correspond to public policy - or, more precisely, to a relinquishment of public authorities to intervene with the sports self-regulation. Furthermore, some public policies provide exemptions or special policies when it comes to professional sports with competitive balance considerations often playing an indirect or direct justification role. Prominent examples include competition policy, investment policy or labour market policy who frequently accommodate restrictive practices by sports associations because of the competitive balance-enhancing effects of these restrictive practices. ${ }^{7}$

\footnotetext{
${ }^{6}$ See, inter alia, Budzinski \& Müller (2013), Budzinski (2014), Budzinski \& Szymanski (2014), Franck (2014), Hamil (2014), Könecke \& Schubert (2014), Maxcy (2014), Peeters \& Szymanski (2014), Preuss, Haugen \& Schubert (2014), and Szymanski (2014).

${ }^{7}$ See for recent discussion regarding U.S. antitrust policy Ross (2003), Kahn (2009) and Zimbalist (2009) and regarding European competition policy Budzinski (2012).
} 


\subsection{The Empirical Record}

The overwhelming popularity of the $\mathrm{UOH}$ and competitive balance in sports economics led to a massive literature looking for empirical evidence. In doing so, three dimensions of competitive balance are usually distinguished (Cairns, Jennett \& Sloane 1986):

- short-term outcome uncertainty, referring to a specified match or single event,

- mid-term outcome uncertainty ${ }^{8}$, referring to in-season sub-competitions such as the race for the championship, the battle against relegation, or the qualifying race for continental competitions (UEFA Europa League; UEFA Champions League), and

- long-term outcome uncertainty, referring to the domination (or lack thereof) of a league or championship by single or few teams over a period of time.

In line with the research discussed in the following sections of this paper, we focus on empirical studies of European professional football. Here, decades of empirical research within sports economics have not been successful in establishing clear evidence for the importance of short-term and long-term outcome uncertainty for stadium attendance or TV audience. ${ }^{9}$ Most of the studies analyzing the potential impact of short-term outcome uncertainty on stadium attendance predominantly found either no significant effect (e.g. Hart, Hutton \& Sharot 1975; Szymanski 2001; Forrest \& Simmons 2002, 2006; Benz, Brandes \& Franck 2009) or an effect not supporting the UOH (e.g. Peel \& Thomas 1992; Czarnitzki \& Stadtmann 2002; Feddersen et al. 2006; Buraimo \& Simmons 2008, 2013; Pawlowski \& Anders 2012). Although there are fewer empirical studies explicitly examining the impact of longterm outcome uncertainty on stadium attendance or TV viewership, the available (partly anecdotal) evidence contradicts the UOH since a slightly increasing imbalance has been accompanied by increasing attendance figures (Flores, Forrest \& Tena 2010; Pawlowski, Breuer \& Hovemann 2010; DFL 2014).

With respect to mid-term outcome uncertainty, however, the picture is less consistent. While a significant positive effect was often detected if a team still had a chance to contend for the championship (Jennett 1984; Pawlowski \& Anders 2012; Scelles et al. 2013) or to earn promotion (Forrest \& Simmons 2002; Scelles et al. 2013), neither the chance to avoid relegation (Jennett 1984) nor to qualify for the UEFA Champions League (Pawlowski \& Anders 2012) was found to be of any apparent importance to consumers. A recent analysis of television audience demand for English premier league football finds no significant effect of mid-term outcome uncertainty; instead, it is the star quality of a team that drives television audience

\footnotetext{
${ }^{8}$ Scelles et al. (2013) refer to mid-term outcome uncertainty as competitive intensity.

${ }^{9}$ For a detailed analysis of the literature see Pawlowski (2013a; 2013b).
} 
(Buraimo \& Simmons 2013). Moreover, looking at longer-run developments, the authors find a tendency away from competitive balance and towards star effects in terms of determinants of television audience demand.

In summary, according to existing economics-related studies "...match attendance [in English professional league soccer] appears unrelated to competitive balance..." (Szymanski 2001) as the studies display "a lack of certainty about outcome uncertainty" in professional football (Leach 2006: 117), rather suggesting a rejection of the $\mathrm{UOH}$. However, we think it might be somewhat premature to jump to the conclusion that competitive balance and outcome uncertainty do not matter for consumers. Instead, the underwhelming empirical record may be related to associating competitive balance and outcome uncertainty to rather global statistical measures which may just not mirror how consumers perceive suspense in a league or a championship. The significance of some mid-term indicators (championship race, promotion/relegation battle) may be viewed as supporting this view that is in line with the statement: "the best measure of competitive balance is the one to which fans show the greatest sensitivity" (Zimbalist 2002: 112). Consequently, another line of analyzing the $\mathrm{UOH}$ may involve measuring the perception of competitive balance through the eyes of the fans (Pawlowski 2013a; b; Pawlowski \& Budzinski 2013 , 2014). Therefore, we first look into some concepts from behavioral economics (sections 3.1-3.3) and subsequently discuss some preliminary empirical evidence from our research (section 3.4).

\section{Behavioural Explanations of Fan Perception of Competitive Balance ${ }^{10}$}

\subsection{The Behavioural Perspective}

If fans followed the model of the perfectly-rational homo oeconomicus, then there should be no difference between statistically measured CB in European football leagues and perceived $C B$ in the eyes of the fans. However, to better understand possible effects of perception that deviate from statistically measured effects, we need to move away from simplistic notions of perfect information, perfectly rational behaviour and textbook-level microeconomics.

During the past five decades, economic research has contributed to enrich our understanding of economic behaviour by introducing branches like behavioural economics, institutional economics and experimental economics into the mainstream of economic thinking. Altogether, they draw an empirically well-supported image of the rational-behaving economic subject that includes imperfect information, subjective and constructive perception as well as rule-following, heuristic behaviour. Cognitive resources are scarce and, consequently, individuals economize on

\footnotetext{
${ }^{10}$ This chapter closely mirrors Pawlowski \& Budzinski (2014).
} 
these resources, which includes limiting information gathering (Simon 1955; Stigler 1961), economizing on the interpretative force of the brain by relying on mental models (Kahneman \& Tversky 1979; Denzau \& North 1994; Kahneman 2003a, 2003b) as well as focusing their scarce cognitive resources on those problems where their employment promises to yield extraordinary revenues and reverting to heuristics-following behaviour in ordinary situations (Budzinski 2003; Vanberg 2004).

This is a world where perception matters and plays a considerable role. Rational behaviour, then, does not so much describe 'right' behaviour in terms of statistical facts, but instead - less ambitiously - the consistency of mind and action. Drawing broadly on a body of economic thought that is enriched by these influences, three possible explanations of the (non-)divergence of objective competitive balance $(\mathrm{OCB})$ and perceived competitive balance (PCB) can be derived: framing effects (3.1), threshold effects (3.2), and attention level effects (3.3). These effects are discussed in the following.

\subsection{Framing Effects}

Framing effects imply that the context of a perception or a decision situation matters for interpretation and action: individuals are framed by past experiences as well as the environment of a situation and this influences how they perceive and interpret a given phenomenon. With respect to $C B$ this means that fans are not influenced by a given CB-value in an isolated way. Instead, that CB-value is perceived in the context of the previous $\mathrm{CB}$-values, which represent the framing of the fans and act as reference points for the individual, subjective valuation. As a consequence, changes in $C B$-values become more important than cardinal levels. If $C B$ has been very low in a given league, then any improvement from that low level may be perceived as "high" CB because fans have been accustomed to low CBlevels and take the past imbalance as a reference point (anchoring effects). On the other hand, if CB-levels are high, a small deterioration of $C B$ may already be perceived as "low" CB because fans have adjusted their reference point to the high level. The subjective assessment of $C B$ is then driven by a mismatch of $C B$ expectation and actual $C B$ : if $C B$ is higher than expected, $P C B$ will likely exceed $O C B$, whereas it will fall short of $O C B$ if $C B$ is lower than expected. ${ }^{11} A$ s a consequence, it

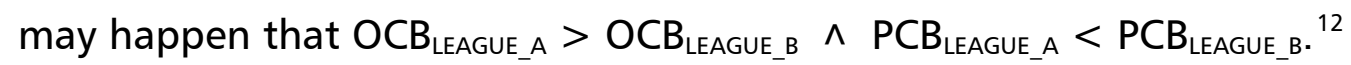

\footnotetext{
${ }^{11}$ In addition to past expressions of $\mathrm{CB}$, expectations can be driven by other influences. For instance, CB-expectation could be extraordinary high because of welcomed rule changes or an extraordinary influx of prominent (star) players (allocated to many teams), etc.

${ }^{12}$ Coates, Humphreys and Zhou (2014) employ a somewhat similar thought on a match level when they model individual consumer choice as depending on a utility function that, inter alia, includes the difference between the actual match outcome and the expected match outcome as a
} 
Consider the following hypothetical example: country $A$, on the one hand, has a comparably imbalanced premier-level league say with CBR-levels oscillating around values of 0.3 . Country B's fans, on the other hand, enjoy a premier-level league with CBR-levels around values of 0.7. Now, in the recent seasons, CBR of League A unexpectedly jumps to 0.45 whereas CBR level of League $B$ unexpectedly drops to 0.55 . While League $B$ remains the more balanced one in $O C B$ terms, framing effects may well drive PCB of (disappointed) League B-fans below the PCB of (positively surprised) League A-fans.

In order to gather some empirical evidence on competitive balance as it is perceived through the eyes of the fans (PCB), we conducted a written survey amongst football fans in three European countries (Germany, Denmark and the Netherlands). The major leagues in these countries differ in regard to size, UEFA ranking position and, naturally, also in terms of OCB. The survey took place before/during 14 matches in the first divisions of the respective leagues both in the stadium as well as in bars where football matches were broadcasted live. The complete data base contains $\mathrm{n}=1,689$ observations (with $\mathrm{n}_{\text {Germany }}=1,203 ; \mathrm{n}_{\text {Denmark }}=267, \mathrm{n}_{\text {Netherlands }}=$ 219). ${ }^{13}$

Indeed, in our study, we find some support for framing effects (Pawlowski \& Budzinski 2013). The decrease in OCB seems to influence perceptions in a stronger way than the level of OCB in the case of the Danish league. Note that the Danish league actually is characterized by a better OCB-value than the premier-level leagues in the Netherlands and in Germany in the first two periods and still better than the Dutch league in the third period (see fig. 1). Yet, the decrease of CB is much more dramatic in Denmark than in the other two leagues. From the first to third period, CBR for Denmark decreased by around 34 per cent (from 0.8 to 0.53 ), whereas for Germany it decreased 'only' by around 12 per cent (from 0.66 to 0.58 ) and the Dutch level increased by around 14 per cent (from 0.36 to 0.42 ). This corresponds to the PCB that shows higher perceived imbalance for the Danish league compared to the other two. So, generalizing over the three periods, we can - a bit simplifying - see that while for $\mathrm{OCB}$ levels $\mathrm{OCB}_{\text {Denmark }}>\mathrm{OCB}_{\text {Germany }}>\mathrm{OCB}_{\text {Netherlands }}$ holds, $\mathrm{PCB}$-levels are characterized by $\mathrm{PCB}_{\text {Denmark }}<\mathrm{PCB}_{\text {Netherlands }}<\mathrm{PCB}_{\text {Germany. }}$.

Thus, the difference between OCB- and PCB-levels may be explained by changes of $C B$ (as a framing factor) being a stronger influence on fans' perception than CBlevels.

(positive or negative) utility source (surprise win by the supported team and surprise loss by the supported team respectively).

${ }^{13}$ For more detailed descriptions of the survey and the methods of analysis see Pawlowski (2013a, 2013b) and Pawlowski \& Budzinski (2013, 2014). 
Fig. 1: Trends in Competitive Balance in the Danish Superligaen (DSL), the Dutch Eredivisie (DED) and the German Bundesliga (GBL) (Pawlowski \& Budzinski 2014)

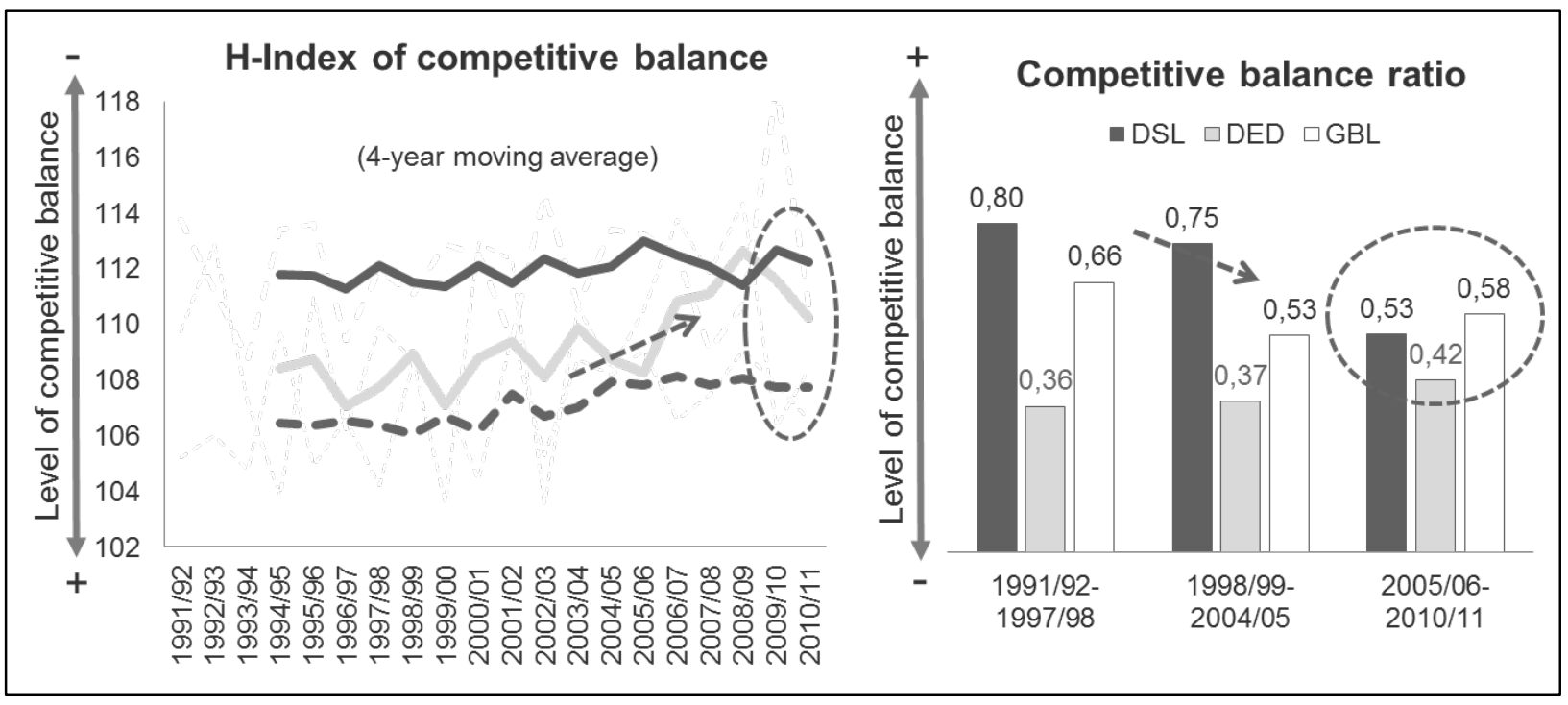

Note: A higher competitive balance ratio implies a more balanced league (Humphreys 2002).

Fig. 2: Perceived Level of Excitement and Willingness-to-pay to Increase the Current Level of Excitement in the Danish Superligaen (DSL), the Dutch Eredivisie (DED) and the German Bundesliga (GBL) (Pawlowski 2013a; Pawlowski \& Budzinski 2013)

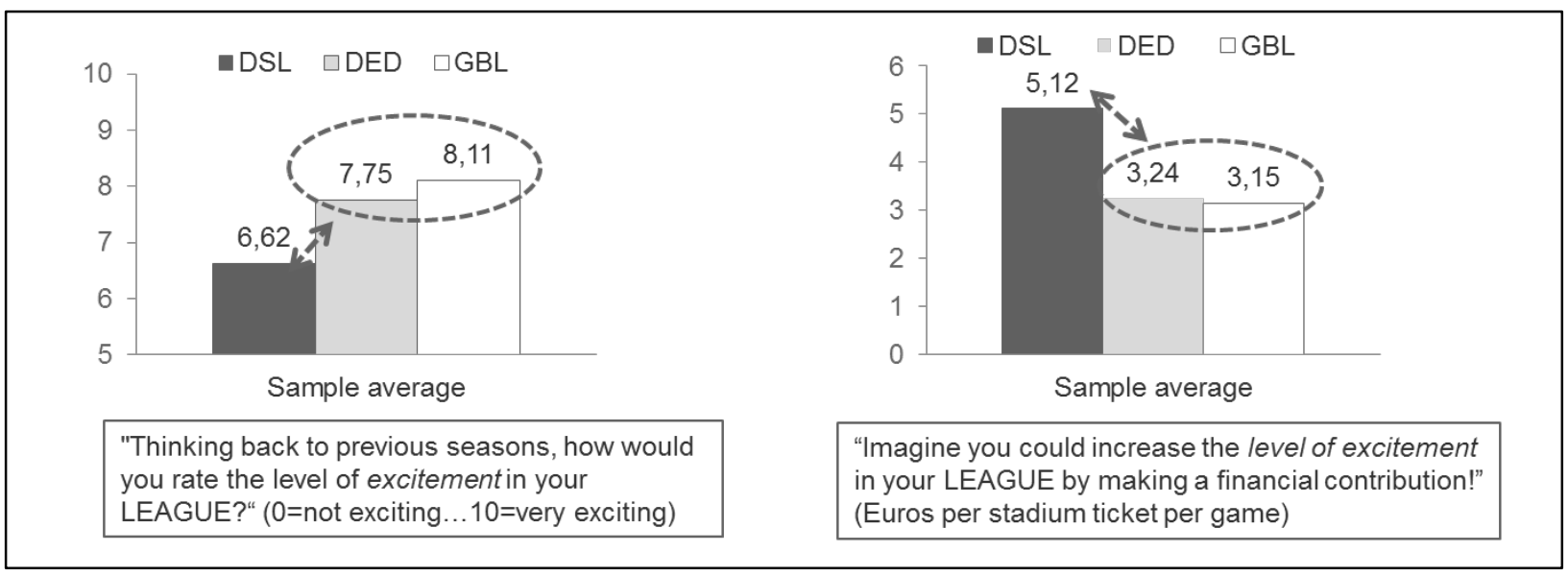

\subsection{Threshold Effects}

Threshold effects correspond to an important behavioural economics-qualification of the concept of optimality: instead of aspiring to an optimal level of satisfaction 
in regard to the consumption of any good, individuals are typically less ambitious and settle for a "satisficing" level. Once a certain level of satisfaction is reached, no further cognitive resources are spent on optimizing the consumption in question. Instead, the scarce cognitive resources are focused on consumption areas where no satisfying level has been reached, yet. In other words, (small) variations above the satisficing level do not matter. However, if the "satisficing" threshold is undercut, then a strong (demand) reaction is triggered (discontinuity effect).

While the empirical evidence for such effects differs among different types of wants and needs as well as among corresponding goods categories, fans' desideratum for balanced competition within the league may provide a fitting example. So far, sports economics research has struggled to identify any optimal level of $C B$; identification of optimum has neither theoretically, nor empirically been managed (see section 2.1.). It appears to be broadly accepted that this, inter alia, has to do with conflicting influences such as the attractiveness of close competition in terms of high uncertainty of outcome and unpredictability of results versus the attractiveness of superstar players and superstar teams that inevitably generate some minimum imbalance. Perfect CB would basically imply a random walk (without any favourites or underdogs) and most sports economists will agree that this is not optimal. An additional factor in question may well be that fans are not interested in any optimal $C B$, i.e. they do not have an (explicit or implicit) notion of an optimum regarding $C B$ themselves. Instead, fans may rather be interested in a satisficing $C B$. In this case, a discontinuity effect emerges: $C B$ changes above the satisficing level of $C B$ are not perceived to be relevant for consumption behaviour whereas a drop of $C B$ below the satisficing level may cause discontinuous, perhaps even extreme consumption reactions.

Again, we find preliminary supportive evidence that the relation between $C B$ and fans' consumption includes a discontinuity in terms of some kind of a "tipping point" or threshold above which changes in $C B$ are not very relevant for fans whereas fans' consumption behavior does change significantly once CB falls below that crucial threshold. While Pawlowski (2013a; 2013b) find that the PCB conditional demand curves are s-shaped (indicating an area of inelastic response for both, very high and very low values of PCB), findings by Pawlowski and Budzinski (2013) suggest that changes in the fans' willingness-to-pay for improvements of $C B$ are triggered by CB falling below a crucial threshold, i.e. WTP 'jumps' to a higher level as a reaction to this. 
Fig. 3: Willingness-to-pay (per stadium ticket per game) to Increase the Current Level of PCB (Pawlowski \& Budzinski 2013: 120)

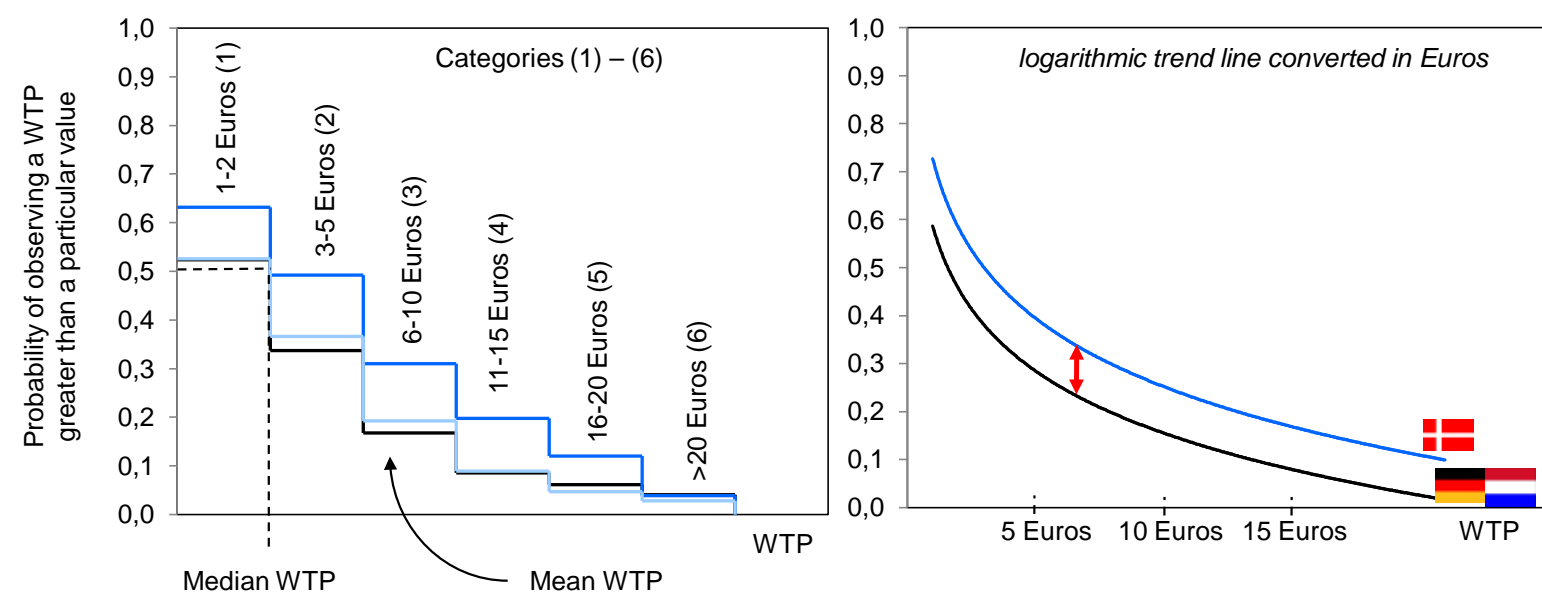

\begin{tabular}{|l|c|c|c|c|}
\hline & $\begin{array}{c}\text { Median WTP } \\
\text { (Categories) }\end{array}$ & $\begin{array}{c}\text { Median WTP } \\
\text { (converted in Euros) }\end{array}$ & $\begin{array}{c}\text { Mean WTP (Std. Err. }{ }^{*} \text { ) } \\
\text { (Categories) }\end{array}$ & $\begin{array}{c}\text { Mean WTP (Std. Err.*) } \\
\text { (converted in Euros) }\end{array}$ \\
\hline Denmark - & 1 & 1.5 & $1.791(.1137)$ & $5.12(.3250)$ \\
\hline Germany - & 1 & 1.5 & $1.216(.0458)$ & $3.15(.1186)$ \\
\hline Netherlands - & 1 & 1.5 & $1.249(.1016)$ & $3.24(.2636)$ \\
\hline
\end{tabular}
* Standard Errors (Std. Err.) were derived by bootstrapping (r=999)

\subsection{Attention Level Effects}

In addition to the theoretical effects and their preliminary supportive evidence discussed above, a third effect might be relevant in this context as valuations of individuals depend on the degree of (their) attention that is drawn to a specific phenomenon. This attention level depends - next to the individual's preferences - on salience-related aspects like media intensity (presence in broadcasting, newspapers, internet, boulevard media, etc.) and relative importance of specific subparts of the overall phenomenon. In regard to the valuation of goods, a typical consequence is that valuations of those products that receive high attention levels outshine those of products with low attention levels in the perception of the consumer.

With respect to the competitive balance of premier-level football leagues, the effects of diverging attention levels may be particularly relevant since the relative importance of competition among teams differs significantly depending on the positions within the league's ranking that these teams are fighting for. Put drastically, competition for top positions is considerably more important than competition in the 'dull' midfield: while the close duel of two teams for championship fame will be associated with high attention levels, a close fight of three teams for position 10 in an 18- or 20-teams league will certainly receive significantly lower attention levels. The relative importance of the championship race is obviously higher than of the 
race for a midfield position ${ }^{14}$ and, correspondingly, media intensity (regarding all dimensions) will be much higher for the former than for the latter.

However, the diverging attention levels can have an important influence on the perception of the competitive balance of the league. Consider the following two scenarios for an 18-teams league: $A$ ) the championship race between three teams is close until the last minute of the season; the three top teams are very evenly matched in terms of performance levels. However, the "race for position 10" is early decided because the differences in competitiveness are rather high among the midfield teams; B) The championship race is decided very early in the season due to the clear dominance of one team that is head and toes above the competition. However, the "race for position 10" is very intense among four teams that are very evenly matched.

It should not be surprising if the $\mathrm{PCB}$ of scenario $A$ was significantly and considerably higher than the PCB of scenario B. However, the standard OCB measures, measuring the $C B$ of the overall league, will not necessarily come to the same result because they do not distinguish between a close fight for position 1 and a close "fight for position 10". So, while statistically (OCB) every sub-competition within the league is associated with the same value, the fans (PCB) will value some subcompetitions higher than others - due to diverging attention levels. Differences between $O C B$ and PCB may be rooted in the phenomenon that $C B$ between (few) top teams may be more important for fan perception than the balance of the league in total.

Looking at typical European soccer premier-level leagues, we can indentify several sub-competitions that exceed the 'ordinary' fight for positions in the league ranking in terms of relative importance and media intensity. These include, for instance, the championship race, the race for the qualification positions for the Europeanlevel competitions (UEFA Champions League; UEFA Europe League), the race against relegation ${ }^{15}$, and qualification positions for play-off rounds (depending on the league's championship structure).

${ }^{14}$ Please note, that competition for midfield positions is relevant in some leagues (e.g. the German Bundesliga) because media revenues are (partly) redistributed based on the past season(s) positioning in the final league table(s). Therefore, different (midfield) positions go along with (slightly) different amounts of club-specific media revenues. However, without any doubt, competition for the top positions is considerably more important for (most of the) fans. Recent sports economics research provides evidence that the same is true for the participants of the league: effort levels for comparably less important midfield position races are lower than such for more important decisions like the race for the championship (Feddersen, Humphreys \& Soebbing 2012).

${ }^{15}$ European football leagues are typically open leagues in which the teams on the last positions in the ranking are relegated to a lower-level league and replaced by the top performers of these power level leagues. 
The consequent hypothesis is that PCB is more driven by the closeness of these comparatively important sub-competitions (i.e. by the $C B$ among the contenders for the relevant positions in the league ranking) than by the $C B$ of the overall league that typically determines the standard $O C B$ measures. If this hypothesis can be supported, then the gap between $P C B$ and $O C B$ will disappear when $O C B$ measures are employed that do not target the league as a whole but focus on the relevant sub-competitions (i.e. mid-term components of league competition).

In addition to the overall index of PCB generated by the survey analysis (see section 3.2. and Fig. 2), the survey consisted of 11 items reflecting the short-, mid- and long-term outcome uncertainty. They were evaluated by the respondents on a 4point scale ( $1 \equiv$ I do not agree $\ldots 4$ I I agree completely) with the following type of question:

Thinking back to previous seasons, what is your opinion of the LEAGUE with regard to...?

Fig. 4 summarizes the mean values for the four items reflecting mid-term outcome uncertainty. In line with the findings for the overall index of PCB, the Danish Superligaen is perceived to be significantly less balanced also with regard to mid-term outcome uncertainty. Specifically, the race for the championship appears to be less balanced as most of the Danish Fans disagree with the statement that the fight for the title remains exciting for a long time within a season. These perceptions by the fans are confirmed by the available 'objective' data. Five years prior to the inquires (season 2006/07-2010/11) there have been four different champions in the German Bundesliga and the Dutch Eredivisie each while FC Copenhagen won all but one championship in Denmark. Furthermore, the "championship relevance" of games further strengthens this result. A game possesses championship relevance if at least one of two teams still has a (mathematical) chance of winning the championship. Significantly, in the season before the inquiry took place (2010/11) only $45 \%$ of the games in Denmark had such championship relevance in contrast to more than $60 \%$ of the games in Germany and the Netherlands.

Fig. 4: Fans' Evaluation of Different Dimensions of Excitement in the Danish Superligaen (DSL), the Dutch Eredivisie (DED) and the German Bundesliga (GBL) (Pawlowski 2013a; Pawlowski \& Budzinski 2014).

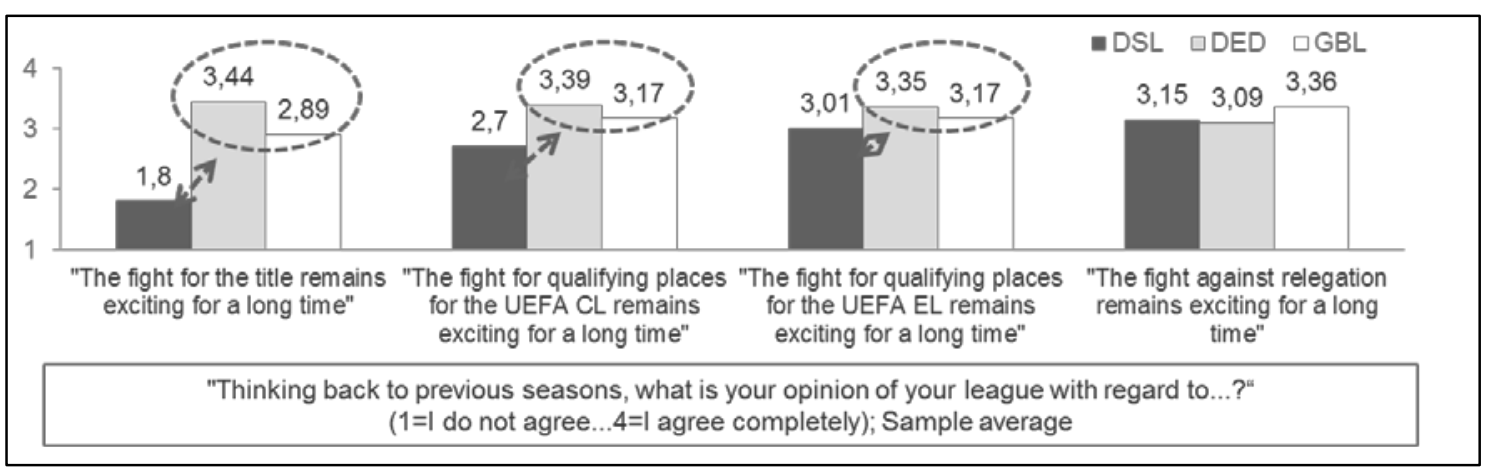


Fig. 5 provides some descriptive evidence based on the average winning margin in three different leagues. While the champions in the Dutch Eredivisie and the German Bundesliga are on average 3.4 respectively 5.2 points ahead, the champions in the Danish Superligaen are on average 12.4 points ahead of the team in second place. In 2010/11, FC Copenhagen was even 26 points ahead of the runner-up Odense BK.

In summary, the stronger imbalance of the Danish league can be found both in perceived and objective measures if mid-term measures are analyzed. For instance, mid-term PCB and mid-term OCB measures both reflect the comparatively strong imbalance of the Danish league when it comes to analysing championship relevance. While the ranking of the Dutch and the German league, which are rather close to each other, is not unambiguous, still the objective and subjective measures show exactly the same pattern, i.e. $\mathrm{OCB}_{\text {Denmark }}<\mathrm{OCB}_{\text {Germany, Netherlands }}$ and $\mathrm{PCB}_{\text {Denmark }}<$

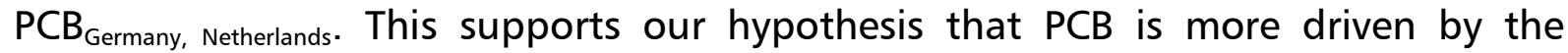
closeness of comparatively important sub-competitions (i.e. by the $\mathrm{CB}$ among the contenders for the relevant positions in the league ranking) than by the $C B$ of the overall league: the imbalance of the championship race in Denmark dominates the balance of the overall league in regard to the assessment and behaviour of the fans.

Fig. 5: Average Number of Points ahead in the Danish Superligaen, the Dutch Eredivisie and the German Bundesliga (Pawlowski \& Budzinski 2014)

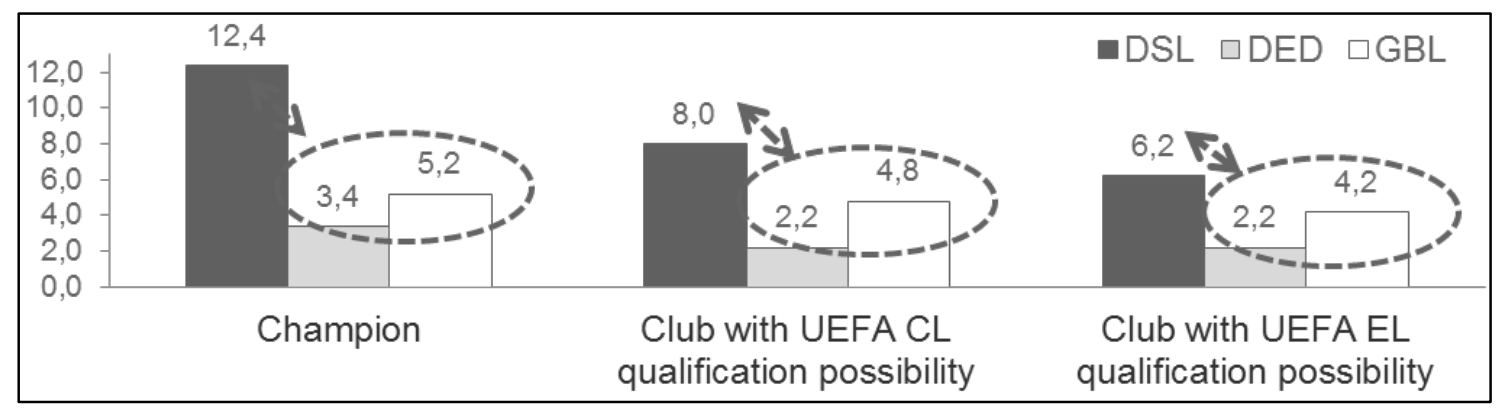

\section{Implications for Sports Policy and Championship Management}

\subsection{Does Competitive Balance Matter for Sports Policy?}

As has been outlined in section 2.2., the preservation and improvement of competitive balance frequently serves as a justification for policy interventions and market regulations - exercised by sports associations and condoned by public authorities - 
that otherwise raise considerable competition concerns. However, the standard theory of competitive balance (summarized in section 2.1.) - as convincing as it appears to be - severely lacks empirical support. It does so to an extent that doubts on the relevance of the 'competitive balance defense' may plausibly be raised. Adding a behavioural view on competitive balance, thus, firstly delivers somewhat good news for balance-enhancing policies: competitive balance matters! However, it is perceived competitive balance that matters and it entails several peculiarities that matter for policy conclusions, namely

- changes in competitive balance are more relevant than levels of competitive balance (section 3.1.),

- the perceived imbalance needs to exceed certain thresholds in order to become relevant for consumption behavior (section 3.2.), and

- measures of mid-term competitive balance better reflect perceived competitive balance than more global indicators, i.e. consumers attention focuses on important sub-competitions and not so much on overall-league suspense (section 3.3.). ${ }^{16}$

The combination of the first and the second result points at situations of unexpected drops of competitive balance levels below certain satisficing thresholds that would trigger discontinuous and severe decreases of demand because of descending fans' marginal utility. These represent situations that must be of concern for championship management (by sports associations, league organizations or promoting companies). Here, the goal of protecting and stabilizing revenues would require $C B$-preserving or -improving interventions. If effective, such interventions would probably not be problematic from a social point of view because they improve the product in the eyes of the fans, thus any revenue increase would come from an increased willingness-to-pay (driven by increasing marginal consumption utility). However, in contrast to the implications of the standard theory and in contrast to common sport policy practice, the validity of the competitive balance defence for restrictive practices and policies is not ubiquitous. It requires rather special situations for trends in competitive balance to actually trigger demand changes. Both the first and second result in the bullet point list above clearly indicate that usually marginal changes in CB will not lead to an according change of fans' consumption behaviour ${ }^{17}$ - in line with the empirical record of decades of research (see

\footnotetext{
${ }^{16}$ These insights point to relevant implications for sports economics research, in particular, to the need for better develop and employ mid-term competitive balance measures (Fort \& Maxcy 2003; Pawlowski \& Budzinski 2014) as well as to consider economic models of leagues or other contests that incorporate sub-competitions (implying a departure from two-team models).

17 If the competition in question was not significantly imbalanced, (comparatively) small changes in competitive balance are unlikely to cause significant consumption reactions because the development of competitive balance remains within a corridor below the critical threshold of too much imbalance perception. Only a major departure from historical competitive balance levels
} 
section 2.3). As long as $C B$ changes are not significant and unexpected (first result) and as long as $C B$ changes remain within a satisficing level, they are not likely to significantly influence fans. Consequently, in such situations, restrictive interventions would only be that: restrictive and anticompetitive without providing a better product to the fans. Note that such interventions may still be interesting from a championship management perspective because they may still lead to higher revenues. However, it is the abuse of market power that yields these higher revenues (at the expense of fans welfare) and not an increasing utility on the side of the fans (as in the special case at the beginning of this paragraph).

Consequently, from an economic perspective, restrictive interventions into competition by sports associations should only be allowed if they fulfil a set of rather restrictive criteria:

(i) competitive imbalance is massive and/or OCB-indices have deteriorated significantly and unexpectedly/in an unanticipated way.

(ii) intervention is capable of improving CB significantly (and not merely marginally).

(iii) there is no less restrictive and less anticompetitive regulation that would be capable of creating comparable CB-improvements.

(iv) generally, interventions with stronger restrictive effects require stronger evidence that (a) a situation is actually harming consumers and (b) applied instruments improve CB more and more secure.

Even without expanding on specific regulations or interventions, it appears to be quite obvious that the competitive balance defence would not apply for many current practices of sport associations that display questionable competitive effects. If market-internal policies and regulations entail non-negligible restrictive effects (like rights bundling and price cartels, limitations of competitive investment (budget caps of any type), restrictive and non-performance based entry regulations, exclusivity equipment contracts, etc.), scepticism towards whether competitive balance effects of these policies and regulations are likely to offset the restrictive effects is justified. From an economic point of view, it requires reliable evidence of the benefits of the probable competitive balance effects of restrictive practices as well as reliable evidence that this CB-change would actually influence PCB before they can be considered as remedying the negative effects. The burden of evidence should fall on the shoulders of the sports associations since (in the case of commercial and professional sports) they enjoy a considerable market power position (see section 2.2) - and thus incentives for championship management are high to reap the rents from abusing this market power.

towards more imbalance (major amounts of change) is likely to influence the perceived competitive balance. 


\subsection{Narrow Oligopolies Fighting for the Championship Instead of Overall Bal ance?}

The more radical conclusion stems from the insight that it is the competition for important decisions (like the championship race or the battle against relegation) that predominantly drives perceived competitive balance. The implication of the overarching importance of these sub-competitions imply that arguing in favour of total league balance is less convincing. Instead, improving overall league balance is less important than improving balance among the limited number of teams 'in the hunt' for important decisions (championship race, etc.). The behavioural view implies that it would be enough to have a sufficient number of teams strong enough to provide a close fight for the championship (ideally not decided before the last match) and it does not matter if the rest of the teams falls significantly behind them. Quite in contrast, it could be particularly beneficial to have an oligopoly of title contenders and an oligopoly of teams battling relegation - and merely few teams in between. Such a league structure may very well promote perceived competitive balance - and fan utility - more than an overall more balanced league.

This line of thought raises the interesting question of how many teams such a beneficial oligopoly of title contenders should consist of. According to standard competition theory, a first thought may point towards rather wide oligopolies consisting of evenly balanced contenders for each subcompetition in question (for the championship, against relegation, for promotion, etc.). However, it would be up to further research whether a championship battle among 6,7 or 8 rather equally strong teams would really be superior to a fight among 3 or 4 teams, for instance. The latter might be sufficient for a satisficing level of perceived competitive balance. Moreover, additionally considering superstar effects à la Adler (1985) (consumption capital accumulation, network effects, commonality effects) and brand effects (Pawlowski \& Anders 2012) may actually point towards the superiority of a narrow oligopoly of predominantly the same teams gunning for the championship each season. In such a narrow oligopoly - in the extreme case a duopoly - fan utility from star and brand phenomena would be increasing compared to a wider oligopoly. In that regard, the Spanish football league with its persistent duopoly of Real Madrid and CF Barcelona duelling for the championship may be more attractive for fans than the more (overall) balanced leagues of Denmark or France, which, however, frequently lack a close championship race. Note, however, that dominance by a single team remains likely to be welfare-reducing in the course of time. As a consequence, a duopoly with a distinct competitive advantage over the rest of the championship may be a risky strategy from a championship management perspective because it may quickly transform into a single team dominating that league. 
The potentially provocative and radical character of these conclusions becomes clear when considering the implications for re-allocation mechanisms or budgetequalizing regulations like equal distribution of TV revenues, gate revenue-sharing, salary caps, reverse draft systems, etc. They all breathe the spirit of overall league competitive balance - but may actually be counterproductive to a good league product since they do not automatically also promote close subcompetitions or may actually go at the expense of those. If some degree of inequality is inevitable (which is theoretically sound if teams are heterogeneous), then attempts to strengthen the weakest ones at the expense of the strongest ones may just reduce the (oligopolistic) number of teams that are able to fight the leader team. Instead of aiming to reduce the gap between the first and the last, it may be more efficient to aim to reduce the gap between the first and the fourth or fifth - because the gap between the top teams and the weakest teams does not matter for consumer utility. If a league should be made more attractive for the fans, then it would be important to enable the second, third and fourth best teams to take the fight to the number one - and not to improve the situation of the twelfth best team. Giving up the thought of equality among all the participants - the famous level-playing field - represents a significant departure from traditions of fairness rhetoric and so on. However, if we talk about a commercial product, then it may be consumer welfare enhancing to move away from 'equality among all' and towards 'ensuring sufficient contenders for close subcompetitions'. This certainly requires creative thinking about rules and regulations. However, it also presents strong support for less interference with competitive forces: the notion of a level-playing field loses some of its support by the economic theory of sports.

\section{Conclusion}

The notion that more competitive balance increases fan utility, therefore their willingness-to-pay, and thus the revenues of commercial and professional sports events has since the pioneering works represented one of the core elements of sports economics. As such, it has served sports associations and authorities as a justification for a wide variety of interventions into the inextricable network of sports and economic competition. Among the more popular interventions, regulations that display (otherwise) restrictive and anticompetitive effects have always played an important role - justified by the competitive balance defense. However, empirical support for this theory has always been ambiguous and ambivalent at best. In addition to the lack of empirical confirmation, new theory developments have also started to cast doubt on the relevance of competitive balance for welfare in commercial sports markets.

In this paper, we contribute to this body of thought by providing a behavioural perspective on the role of competitive balance in commercial sports leagues, using 
(European-style) football leagues as an example. From a theoretical perspective, we argue that perceived competitive balance should differ from statistically-measured 'objective' competitive balance, for instance because of framing effects, satisficing and threshold effects as well as attention level effects. Based upon an international research project, we provide empirical support for the relevance of the behavioural view. While we find that perceived competitive balance matters for fan utility and demand behaviour, it does not do so in the maximizing sense of the standard theory: above a satisficing level of statistical competitive balance, fans do not perceive differences as relevant. However, if the CB-level falls under the satisficing threshold, discontinuous demand reactions must be expected. Furthermore, fans may perceive similar OCB-levels very differently depending on the framing by experience and expectations. Eventually, theory suggests and the empirical picture indicates that fans perception is not driven by overall competitive balance of the league in total as the standard theory - sometimes explicitly but also often implicitly - assumes. Instead, important subcompetitions like the race for the championship or the fight against relegation influence the perceived competitive balance significantly more than the total picture.

The theoretical and empirical extension of sports economics thinking provides important conclusions for the assessment of interventions into commercial sports markets by sports associations or public authorities. While a competitive balance defense may actually be valid, it requires very specific situations and conditions to justify otherwise restrictive interventions and regulations by competitive balance improvements. Most common practices in this area, however, are unlikely to stand in line with behavioural economics thinking. We argue that competitive balance defenses against restrictive and anticompetitive regulations should only be alimented by public authorities under restrictive conditions with considerable evidence burden on the sports associations. Otherwise, the most typically market power positions of the associations set incentives to reap anticompetitive rents at the expense of fans and other parties under the smoke screen of competitive balance policies.

The insight that balanced subcompetitions are considerably more relevant than total league balance may have far-reaching implications. Many standard regulations applied in most commercial sports target an improvement of total league balance, i.e. reducing the gap between the best (richest) and the worst (poorest) team. This is often associated with the notion of a level-playing field. Examples of such regulations include revenue-sharing arrangements, salary caps, centralized marketing, reverse talent draft systems, and many more. However, the attempts to create more balance between the strongest and the weakest appears to be irrelevant to fan welfare at best and harmful at worst. A close race for the championship among few popular contenders and large differences to the lower parts of the ranking serves fan utility more than an overall very balanced league with a champion that is 
crowned early in the season or than an overall balanced league were teams without contours, star effects and profile randomly take the honours. Further research is necessary to shed light on optimal sizes of oligopolies of subcompetition contenders and regulations that promote this. However, it appears to be a case in favour of less intervention into the competitive forces in the first place. 


\section{References}

Adler, M. (1985), Stardom and Talent, in: American Economic Review, Vol. 75, pp. 208-212.

Atkinson, S., Stanley, L. \& Tschirhart, J. (1988), Revenue Sharing as an Incentive in an Agency Problem: an Example from the National Football League, in: Rand Journal of Economics, Vol. 19 (1), pp. 27-43.

Benz, M.-A., Brandes, L. \& Franck, E. (2009), Do Soccer Associations Really Spend on a Good Thing? Empirical Evidence on Heterogeneity in the Consumer Response to Match Uncertainty of Outcome, in: Contemporary Economic Policy, Vol. 27 (2), pp. 216-235.

Budzinski, O. (2003), Cognitive Rules, Institutions, and Competition, in: Constitutional Political Economy, Vol. 14 (3), pp. 215-235.

Budzinski, O. (2012), The Institutional Framework for Doing Sports Business: Principles of EU Competition Policy in Sports Markets, in: International Journal of Sport Management and Marketing, Vol. 11 (1-2), pp. 44-72.

Budzinski, O. (2014), The Competition Economics of Financial Fair Play, in: $O$. Budzinski \& A. Feddersen (eds.), Contemporary Research in Sports Economics: Proceedings of the $5^{\text {th }}$ ESEA Conference, Frankfurt a.M.: Lang, pp. 77-98.

Budzinski, O. \& Müller, A. (2013), Finanzregulierung und internationale Wettbewerbsfähigkeit: Der Fall Deutsche Bundesliga, in: $R$. Dewenter, J. Haucap \& C. Kehder (eds.), Wettbewerb und Regulierung in Medien, Politik und Märkten, Nomos: Baden-Baden, pp. 261-290.

Budzinski, O. \& Szymanski, S. (2014), Are Restrictions of Competition by Sports Associations Horizontal or Vertical in Nature?, in: Journal of Competition Law \& Economics, forthcoming.

Buraimo, B. \& Simmons, R. (2008), Do Sports Fans Really Value Uncertainty of Outcome? Evidence from the English Premier League, in: International Journal of Sport Finance, Vol. 3 (3), pp. 146-155.

Buraimo, B. \& Simmons, R. (2013), Outcome Uncertainty or Star Quality? Television Audience Demand for English Premier League Football, manuscript.

Cairns, J. P., Jennett, N. \& Sloane, P. (1986), The Economics of Professional Team Sports: A Survey of Theory and Evidence, in: Journal of Economic Studies, Vol. 13 (1), pp. 3-80.

Coates, D. \& Humphreys, B. R. (2010), Week to Week Attendance and Competitive Balance in the National Football League, in: International Journal of Sport Finance, Vol. 5 (4), pp. 239-252.

Coates, D. \& Humphreys, B. R. (2012), Game Attendance and Outcome Uncertainty in the National Hockey League, in: Journal of Sports Economics, Vol. 13 (4), pp. 364-377.

Coates, D., Humphreys, B. R. \& Zhou, L. (2014), Outcome Uncertainty, ReferenceDependent Preferences and Live Game Attendance, in: Economic Inquiry, forthcoming. 
Czarnitzki D. \& Stadtmann, G. (2002), Uncertainty of Outcome versus Reputation: Empirical Evidence for the First German Football division, in: Empirical Economics, Vol. 27, pp. 101-112.

Denzau, A. T. \& North, D. C. (1994), Shared Mental Models - Ideologies and Institutions, in: Kyklos, Vol. 47 (1), pp. 3-31.

Depken, C. A. (1999), Free Agency and the Competitiveness of MLB, in: Review of Industrial Organization, Vol. 14 (3), pp. 205-217.

DFL (2014), Bundesliga Report 2014: Die wirtschaftliche Situation im Lizenzfußball, Frankfurt a.M.: DFL.

El-Hodiri, M. \& Quirk, J. (1971), An Economic Model of a Professional Sports League, in: Journal of Political Economy, Vol. 79, pp. 1302-1319.

Feddersen, A., Borcherding, M. \& Maennig, W. (2006), The Novelty Effect of the New Football Stadia: The Case of Germany, in: International Journal of Sport Finance, Vol. 1 (3), pp. 174-188.

Feddersen, A., Humphreys, B. R. \& Soebbing, B. P. (2012), Contest Incentives in European Football, Working Ppaer No. 2012-13, University of Alberta.

Flores, R., Forrest, D. \& Tena, J. D. (2010), Impact on Competitive Balance from Allowing Foreign Players in a Sports League: Evidence from European Soccer, in: Kyklos, Vol. 63, pp. 546-557.

Forrest, D. \& Simmons, R. (2002), Outcome Uncertainty and Attendance Demand: The Case of English Soccer, in: Journal of the Royal Statistical Society, Series D (The Statistician), Vol. 51, pp. 229-241.

Forrest, D. \& Simmons, R. (2006), New Issues in Attendance Demand: The Case of the English Football League, in: Journal of Sports Economics, Vol. 7 (3), pp. 247266.

Forrest, D., Beaumont, J., Goddard, J. \& Simmons, R. (2005), Home Advantage and the Debate about Competitive Balance in Professional Sports Leagues, in: Journal of Sports Sciences, Vol. 23, pp. 439-445.

Forrest, D., Simmons, R. \& Buraimo, B. (2005), Outcome Uncertainty and the Couch Potato Audience, in: Scottish Journal of Political Economy, Vol. 52, pp. 641-661.

Fort, R. \& Maxcy, J. (2003), Competitive Balance in Sports Leagues: An Introduction, in: Journal of Sports Economics, Vol. 4 (2), pp. 154-160.

Fort, R. \& Quirk, J. (1995), Cross-Subsidization, Incentives and Outcomes in Professional Team Sports Leagues, in: Journal of Economic Literature, Vol. 33 (3), pp. 1265-1299.

Franck, E. (2014), Financial Fair Play in European Club Football - What is it All About?, in: International Journal of Sports Finance, Vol. 9 (3), forthcoming.

Franck, E. \& Nüesch, S. (2007), Avoiding 'Star Wars': Celebrity Creation as Media Strategy, in: Kyklos, Vol. 60 (2), pp. 211-230. 
Haan, M., Koning, R. H. \& van Witteloostuijn, A. (2007), Competitive Balance in National European Soccer Competitions, in: Albert, J. \& Koning, R. H. (eds.), Statistical Thinking in Sports, London: Chapman \& Hall: pp. 63-76.

Hamil, S. (2014), Financial Fair Play - Why Loss-Making Is a Problem, in: $O$. Budzinski \& A. Feddersen (eds.), Contemporary Research in Sports Economics: Proceedings of the $5^{\text {th }}$ ESEA Conference, Frankfurt a.M.: Lang, pp. 37-58.

Hart, R. A., Hutton, J. \& Sharot, T. (1975), A Statistical Analysis of Association Football Attendances, in: Applied Statistics, Vol. 24 (1), pp. 17-27.

Humphreys, B. R. (2002), Alternative Measures of Competitive Balance in Sports Leagues, in: Journal of Sports Economics, Vol. 3 (2), pp. 133-148.

Janssens, P. \& Késenne, S. (1987), Belgian Football Attendances, in: Tijdschrift voor Economie en Management, Vol. 32, pp. 305-315.

Jennett, N. (1984), Attendances, Uncertainty of Outcome and Policy in Scottish League Football, in: Scottish Journal of Political Economy, Vol. 31, pp. 176-198.

Kahn, L. M. (2009), Sports, Antitrust Enforcement and Collective Bargaining, in: The Antitrust Bulletin, Vol. 54 (4), pp. 857-881.

Kahneman, D. \& Tversky, A. (1979), Prospect Theory: An Analysis of Decision under Risk, in: Econometrica, Vol. 47 (2), pp. 263-292.

Kahneman, D. (2003a), A Psychological Perspective on Economics, in: The American Economic Review, Vol. 93 (2), pp. 162-168.

Kahneman, D. (2003b), Maps of Bounded Rationality: Psychology for Behavioral Economics, in: The American Economic Review, Vol. 93 (5), pp. 1449-1475.

Kahneman, D., Knetsch, J. L. \& Thaler, R. H. (1991), Anomalies: The Endowment effect, Loss Aversion, and Status Quo Bias, in: The Journal of Economic Perspectives, Vol. 5 (1), pp. 193-206.

Késenne, S. (2000), Revenue Sharing and Competitive Balance in Professional Team Sports in: Journal of Sports Economics, Vol. 1 (1), pp. 56-65.

Könecke, T. \& Schubert, M. (2014), Socio-economic Doping and Enhancement in Sport: A Case-based Analysis of Dynamics and Structural Similarities, in: $O$. Budzinski \& A. Feddersen (eds.), Contemporary Research in Sports Economics: Proceedings of the $5^{\text {th }}$ ESEA Conference, Frankfurt a.M.: Lang, pp. 99-116.

Leach, S. A. (2006), Financial viability and competitive balance in English football, University of London: London.

MacDonald, G. (1988), The Economics of Rising Stars, in: American Economic Review, Vol. 78, pp. 155-166.

Maxcy, J. (2014), The American View on Financial Fair Play, in: O. Budzinski \& A. Feddersen (eds.), Contemporary Research in Sports Economics: Proceedings of the $5^{\text {th }}$ ESEA Conference, Frankfurt a.M.: Lang, pp. 59-75.

Michie, J. \& Oughton, C. (2004), Competitive Balance in Football: Trends and Effects, Research Paper 2004 No. 2, London: University of London. 
Neale, W. C. (1964), The Peculiar Economics of Professional Sports: a Contribution to the Theory of the Firm in Sporting Competition and in Market Competition, in: Quarterly Journal of Economics, Vol. 78 (1), pp. 1-14.

Pawlowski, T. \& Anders, C. (2012), Stadium Attendance in German Professional Football: The (Un)Importance of Uncertainty of Outcome Reconsidered, in: Applied Economics Letters, Vol. 19, pp. 1553-1556.

Pawlowski, T. \& Budzinski, O. (2013), The (Monetary) Value of Competitive Balance for Sport Consumers - A Stated Preference Approach to European Professional Football, in: International Journal of Sport Finance, Vol. 8 (2), pp. 112-123.

Pawlowski, T. \& Budzinski, O. (2014), Competitive Balance and Attention Level Effects: Theoretical Considerations and Empirical Evidence, in: O. Budzinski \& A. Feddersen (eds.), Contemporary Research in Sports Economics: Proceedings of the $5^{\text {th }}$ ESEA Conference, Frankfurt a.M.: Lang, pp. 149-162.

Pawlowski, T. (2013a), Wettbewerbsintensität im Profifußball - Eine empirische Untersuchung zur Bedeutung für die Zuschauer, Wiesbaden: Springer-Gabler.

Pawlowski, T. (2013b), Testing the Uncertainty of Outcome Hypothesis in European Professional Football: A Stated Preference Approach, in: Journal of Sports Economics, Vol. 14 (4), pp. 341-367.

Pawlowski, T., Breuer, C. \& Hovemann, A. (2010), Top Clubs' Performance and the Competitive Situation in European Domestic Football Competitions, in: Journal of Sports Economics, Vol. 11, pp. 186-202.

Peel, D. A. \& Thomas, D. A. (1992), The Demand for Football: Some Evidence on Outcome Uncertainty, in: Empirical Economics, Vol. 17 (2), pp. 323-331.

Peeters, T. \& Szymanski, S. (2014), Financial Fair Play: Winners and Losers on and off the Pitch, in: O. Budzinski \& A. Feddersen (eds.), Contemporary Research in Sports Economics: Proceedings of the $5^{\text {th }}$ ESEA Conference, Frankfurt a.M.: Lang, pp. 17-33.

Preuss, H., Haugen, K., \& Schubert, M. (2014), UEFA Financial Fair Play: The Curse of Regulation, in: European Journal of Sport Studies, Vol. 2 (1), pp. 33-51.

Rosen, Sherwin (1981), The Economics of Superstars, in: American Economic Review, Vol. 71 (5), pp. 845-858.

Ross, S. F. (2003), Competition Law as a Restraint on Monopolistic Exploitation by Sports Leagues and Clubs, in: Oxford Review of Economic Policy, Vol. 19 (4), pp. 569-584.

Rottenberg, S. (1956), The Baseball Player's Labour Market, in: Journal of Political Economy, Vol. 64 (3), pp. 242-258.

Scelles, N. et al. (2013), Competitive Balance versus Competitive Intensity Before a Match: Is One of These Two Concepts More Relevant in Explaining Attendance?, in: Applied Economics, Vol. 45 (29), pp. 4184-4192.

Simon, H. A. (1955), A Behavioral Model of Rational Choice, in: The Quarterly Journal of Economics, Vol. 69 (1), pp. 99-118. 
Stigler, G. J. (1961), The Economics of Information, in: Journal of Political Economy, Vol. 69, pp. 213-225.

Szymanski, S. (2001), Income Equality, Competitive Balance and the Attractiveness of Team Sports, in: The Economic Journal, Vol. 111, pp. 69-84.

Szymanski, S. (2006a), Tilting the Playing Field: Why a Sports League Planner Would Choose Less, Not More, Competitive Balance, IASE Working Paper 06-20.

Szymanski, S. (2006b), Uncertainty of Outcome, Competitive Balance and the Theory of Team Sports, in: Andreff, W. \& Szymanski, S. (eds.), Handbook on the Economics of Sport, Cheltenham: Elgar: pp. 597-600.

Szymanski, S. (2014), Fair Is Foul: A Critical Analysis of UEFA Financial Fair Play, in: International Journal of Sports Finance, Vol. 9 (3), forthcoming.

Szymanski, S. \& Késenne, S. (2004), Competitive Balance and Gate Revenue Sharing in Team Sports, in: The Journal of Industrial Economics, Vol. 52 (1), pp. 165-177.

Vanberg, V. J. (2004), The Rationality Postulate in Economics: Its Ambiguity, Its Deficiency and Its Evolutionary Alternative, in: Journal of Economic Methodology, Vol. 11 (1), pp. 1-29.

Vrooman, J. (1995), A General Theory of Professional Sports Leagues, in: Southern Economic Journal, Vol. 61 (4), pp. 971-990.

Zimbalist, A. S. (2002), Competitive Balance in Sports Leagues: An Introduction, in: Journal of Sports Economics, Vol. 3 (2), pp. 111-121.

Zimbalist, A. S. (2009), The BCS, Antitrust and Public Policy, in: The Antitrust Bulletin, Vol. 54 (4), pp. 823-855. 


\section{Diskussionspapiere aus dem Institut für Volkswirtschaftslehre der Technischen Universität IImenau}

Nr. 42 Steinrücken, Torsten; Jaenichen, Sebastian: Wer ist wirklich reich? - Zu Problemen der Wohlfahrtsmessung durch das Bruttoinlandsprodukt, April 2005.

Nr. 43 Steinrücken, Torsten; Jaenichen, Sebastian: Wo bleiben die Subventionssteuern? - Probleme des Beihilfenrechts und ein alternatives Regulierungskonzept, Mai 2005.

Nr. 44 Jaenichen, Sebastian; Steinrücken, Torsten; Schneider, Lutz: Zu den ökonomischen Wirkungen gesetzlicher Feiertage - Eine Diskussion unter besonderer Berücksichtigung der Arbeitszeitpolitik, Juni 2005.

Nr. 45 Kuchinke, Björn A.: Qualitätswettbewerb zwischen deutschen Akutkrankenhäusern unter besonderer Berücksichtigung von DRG und Budgets, Juni 2005.

Nr. 46 Kuchinke, Björn A.; Walterscheid, Heike: Wo steht der Osten? Eine ökonomische Analyse anhand von Wohlfahrts- und Happinessindikatoren, Juni 2005.

Nr. 47 Kuchinke, Björn A.; Schubert, Jens M.: Staatliche Zahlungen an Krankenhäuser: Eine juristische und ökonomische Einschätzung nach Altmark Trans und der Entscheidung der Kommission vom 13.7.2005, August 2005.

Nr. 48 Steinrücken, Torsten; Jaenichen, Sebastian: Überkapazitäten zur Absicherung politischer Risiken und Instrumente finanzwirtschaftlicher Gegensteuerung, November 2005.

Nr. 49 Jaenichen, Sebastian; Steinrücken, Torsten: Opel, Thüringen und das Kaspische Meer, Januar 2006.

Nr. 50 Kallfaß, Hermann H.: Räumlicher Wettbewerb zwischen Allgemeinen Krankenhäusern, Februar 2006.

Nr. 51 Sickmann, Jörn: Airport Slot Allocation, März 2006.

Nr. 52 Kallfaß, Hermann H.; Kuchinke, Björn A.: Die räumliche Marktabgrenzung bei Zusammenschlüssen von Krankenhäusern in den USA und in Deutschland: Eine wettbewerbsökonomische Analyse, April 2006.

Nr. 53 Bamberger, Eva; Bielig, Andreas: Mehr Beschäftigung mittels weniger Kündigungsschutz? Ökonomische Analyse der Vereinbarungen des Koalitionsvertrages vom 11. 11. 2005, Juni 2006. 
Nr. 54 Jaenichen, Sebastian; Steinrücken, Torsten: Zur Ökonomik von Steuergeschenken - Der Zeitverlauf als Erklärungsansatz für die effektive steuerliche Belastung, Dezember 2006.

Nr. 55 Jaenichen, Sebastian; Steinrücken, Torsten: Wirkt eine Preisregulierung nur auf den Preis? Anmerkungen zu den Wirkungen einer Preisregulierung auf das Werbevolumen, Mai 2007.

Nr. 56 Kuchinke, B. A.; Sauerland, D.; Wübker, A.: Determinanten der Wartezeit auf einen Behandlungstermin in deutschen Krankenhäusern - Ergebnisse einer Auswertung neuer Daten, Februar 2008.

Nr. 57 Wegehenkel, Lothar; Walterscheid, Heike: Rechtsstruktur und Evolution von Wirtschaftssystemen - Pfadabhängigkeit in Richtung Zentralisierung?, Februar 2008.

Nr. 58 Steinrücken, Torsten; Jaenichen, Sebastian: Regulierung und Wohlfahrt in einem Modell mit zwei Aktionsparametern, März 2008.

Nr. 59 Lehnert, Ninja M.: Externe Kosten des Luftverkehrs - Ein Überblick über den aktuellen Stand der Diskussion, April 2008.

Nr. 60 Walterscheid, Heike: Reformbedarf etablierter Demokratien im Kontext dezentralisierter Gesellschaftssysteme - Grundlegende Hindernisse bei Steuersystemreformen", April 2010.

Nr. 61 Walterscheid, Heike; Wegehenkel, Lothar: Kostenstruktur, Zahlungsbereitschaft und das Angebot von Mediengütern auf Medienmärkten, Juni 2008.

Nr. 62 Walterscheid, Heike; Wegehenkel, Lothar: Wohlstand der Nationen und handlungsrechtliche Struktur eines Gesellschaftssystems, September 2008.

Nr. 63 Dewenter, Ralf; Haucap, Justus; Wenzel, Tobias: Indirect Network Effects with Two Salop Circles: The Example oft the Music Industry, Juni 2009.

Nr. 64 Dewenter, Ralf; Jaschinski, Thomas; Wiese, Nadine: Wettbewerbliche Auswirkungen eines nichtneutralen Internets, Juli 2009.

Nr. 65 Dewenter, Ralf; Haucap, Justus; Kuchinke, Björn A.: Das Glück und Unglück von Studierenden aus Ost- und Westdeutschland: Ergebnisse einer Befragung in Ilmenau, Bochum und Hamburg, Oktober 2009.

Nr. 66 Kuchinke, Björn A.; Zerth, Jürgen; Wiese, Nadine: Spatial Competition between Health Care Providers: Effects of Standardization, Oktober 2009. 
Nr. 67 Itzenplitz, Anja; Seifferth-Schmidt, Nicole: Warum Klimakonferenzen scheitern, aber dennoch zum Wohl des Weltklimas kooperiert wird, Juli 2010.

Nr. 68 Kallfaß, Hermann H.: Die Aufmerksamkeit für, die Nutzung der und die Werbung in Medien in Deutschland, November 2010.

Nr. 69 Budzinski, Oliver: Empirische Ex-Post Evaluation von wettbewerbspolitischen Entscheidungen: Methodische Anmerkungen, Januar 2012.

Nr. 70 Budzinski, Oliver: The Institutional Framework for Doing Sports Business: Principles of EU Competition Policy in Sports Markets, January 2012.

Nr. 71 Budzinski, Oliver; Monostori, Katalin: Intellectual Property Rights and the WTO, April 2012.

Nr. 72 Budzinski, Oliver: International Antitrust Institutions, Juli 2012.

Nr. 73 Lindstädt, Nadine; Budzinski, Oliver: Newspaper vs. Online Advertising Is There a Niche for Newspapers in Modern Advertising Markets?

Nr. 74 Budzinski, Oliver; Lindstädt, Nadine: Newspaper and Internet Display Advertising - Co-Existence or Substitution?, Juli 2012b.

Nr. 75 Budzinski, Oliver: Impact Evaluation of Merger Control Decisions, August 2012.

Nr. 76 Budzinski, Oliver; Kuchinke, Björn A.: Deal or No Deal? Consensual Arrangements as an Instrument of European Competition Policy, August 2012.

Nr. 77 Pawlowski, Tim, Budzinski, Oliver: The (Monetary) Value of Competitive Balance for Sport Consumers, Oktober 2012.

Nr. 78 Budzinski, Oliver: Würde eine unabhängige europäische Wettbewerbsbehörde eine bessere Wettbewerbspolitik machen?, November 2012.

Nr. 79 Budzinski, Oliver; Monostori, Katalin; Pannicke, Julia: Der Schutz geistiger Eigentumsrechte in der Welthandelsorganisation - Urheberrechte im TRIPS Abkommen und die digitale Herausforderung, November 2012.

Nr. 80 Beigi, Maryam H. A.; Budzinski, Oliver: On the Use of Event Studies to Evaluate Economic Policy Decisions: A Note of Caution, Dezember 2012.

Nr. 81 Budzinski, Oliver; Beigi, Maryam H. A.: Competition Policy Agendas for Industrializing Countries, Mai 2013. 
Nr. 82 Budzinski, Oliver; Müller, Anika: Finanzregulierung und internationale Wettbewerbsfähigkeit: der Fall Deutsche Bundesliga, Mai 2013.

Nr. 83 Doose, Anna Maria: Methods for Calculating Cartel Damages: A Survey, Dezember 2013.

Nr. 84 Pawlowski, Tim; Budzinski, Oliver: Competitive Balance and Attention Level Effects: Theore-tical Considerations and Preliminary Evidence, März 2014.

Nr. 85 Budzinski, Oliver: The Competition Economics of Financial Fair Play, März 2014.

Nr. 86 Budzinski, Oliver; Szymanski, Stefan: Are Restrictions of Competition by Sports Associations Horizontal or Vertical in Nature?, März, 2014.

Nr. 87 Budzinski, Oliver: Lead Jurisdiction Concepts Towards Rationalizing Multiple Competition Policy Enforcement Procedures, Juni 2014.

Nr. 88 Budzinski, Oliver: Bemerkungen zur ökonomischen Analyse von Sicherheit, August 2014. 